\title{
Does visual merchandising, store atmosphere and private label product influence impulse buying? Evidence in Jakarta
}

\author{
Pristiana Widyastuti \\ Universitas 17 Agustus 1945 Jakarta, Indonesia \\ Faculty of Economic and Business
}

\section{Keyword}

Visual merchandising, store atmosphere, private label, impulse buying

\begin{abstract}
The phenomenon of the proliferation of retail business in Indonesia would be coupled with a very tight competition among them. Retailer has forces to create the right strategy in attracting consumers' buying. This research is analyzing the factors that influence impulse buying which measured by variables as visual merchandising, store atmosphere and private label product. The data is obtained by distribute questionnaire to 125 respondents. The hypothesis is tested using Structural Equation Models (SEM) with Partial Least Square (PLS) as statistical tools. The result revealed visual merchandising which is measured by windows display, mannequin, floor merchandising and assortment has positive and significant effect on impulse buying. Attractive store atmosphere has positive and significant effect on it which is measured by lighting, layout, visual communication (color) and scent on the store. The mount of impulse buying can also be affected by creating private label product. The unique packaging and low price really diluted by consumers. These three aspects proved become determinant factors affecting impulse buying
\end{abstract}

Corresponding author: Pristiana Widyastuti

Email addresses for corresponding author: pristia.widya@gmail.com

First submission received: $27^{\text {th }}$ August 2017

Revised submission received: 22 ${ }^{\text {nd }}$ October 2017

Accepted: 10th November 2017

\section{Introduction}

Indonesia has the fifth ranked in developing countries after China, India, Malaysia and Kazakhstan in the Global Retail Development Index (GRDI) released by the global consulting firm AT Kearney in 2016 (source http://www.beritasatu.com/ Publication Tuesday, June 07, 2016). This rank is obtained because Indonesia is considered to have a huge potential to develop the retail market. The huge population and the development of a retail market that has not been comprehensive in suburb area provide an attraction for investors to develop retail market in Indonesia. Retailer has droves to a massive expansion by opening new outlets in Indonesia. In addition, by 2016 foreign retailers such as Lulu from UAE has established retail in Indonesia after previously well-known foreign retailers such as Hypermart, Lotte and Giant (Hero).

Based on data from the Association of Indonesian Retail Entrepreneurs (APRINDO), the total value of retail sales in 2015 amounted to 181 trillion rupiah (source http://bisnis.liputan6.com// publication December 28, 2016). One of the major retail categories of its development is retailers for fast moving consumer goods (FMCG). Growth of FMCG retailers in Indonesia rose by $10.8 \%$ in 2015 in all segments with a minimarket spread of $11 \%$ and hypermarket $10.6 \%$. Market size obtained by 73 trillion rupiah from the period 2012-2015 with 13\% increase annually (source http:/ / duniaindustri.com/ accessed Wednesday, January 18, 2017). Retail business for household consumption products has a long prospect because it is always needed.

The phenomenon of the proliferation of retail in Indonesia would be coupled with a very tight competition among them. Retailer has forces to create the right strategy in attracting consumers' buying. The most fundamental and major strategy is retailer has to know the consumer behavior; it becomes the target market for the company and the key to win the market competition. One of the consumer behaviors which are targeted by retailers is the impulse buyer. Impulsive behavior according to Schiffman and 
Kanuk (2007) is an emotional or urgent decision. Impulsive purchase is the tendency of consumers to buy spontaneously, reflex, abruptly and immediately (Rook and Fisher 1995). Impulse buyer is a buying product where the buyer has no previous plan (unplanned in shopping list). Potential buyers are not only emphasized on the expenditure of the shopping list only, but purchases from the unplanned list. Impulse buying is influenced by the emotions of buyers. (Li 2015) argue that the impulsive buying behavior induced much higher levels of happiness and guilt. Jung (2017) suggest that the influential motive for impulsivity can increase the enjoyment that buyers get from making purchases and can also have a positive effect on their mood. Consumers buy product for some reasons than because of strictly necessary, such as to relieve a depressed mood, express an identity, or simply for fun. (Verplanken and Herabadi 2001). Retailers are aware that a substantial buyer is generated by impulsive buying.

The consumer's impulsive behavior can be affected by what they see in a retail store. There is something that attracts the consumer to come closer at the store and even for buying products. Retail stores need to organize the look of the store as well and attractive for the consumer. Store arrangement through visual merchandising not only as magnificence, but also must has the allure to increase the interest of buyers to at least come to the store, and then buy the product. Visual merchandising displays use creative techniques in order to save both the sales person's and the shopper's time by making shopping effortless. The visual merchandising display process is often referred to as the "silent sales person" by providing the consumers with information through visual mediums, as well as by suggestive selling - suggestions to add items to a consumer's original purchase (Bhalla \& Anuraag, 2010). Visual merchandising is also in-store decoration that is designed to enhance the customer's comfort and convenience while shopping. The overall aim is to enhance the consumers overall shopping experience (Cant, 2013b). Good visual merchandising is expected to increase consumer desire to buy the product. Khandai (2012) suggests that visual merchandising practices like window display and instore/mannequin display serve as strong stimuli, inducing and motivating the consumer to make an unplanned purchase decision upon entering the store Visual merchandising displays guide consumers in the direction of the products they are seeking and that it guides their product choice (Cant, 2013a). There is a significant positive relationship between the visual merchandises and the customer buying behavior. Also the findings show that for the brand sales visual merchandises is the important factor to purchase the brand (Singh, 2015).

Besides visual merchandising, other factor that allegedly which is able to increase interest and intention of purchase is store atmosphere. Atmospherics are important in situations where the seller can control over the service environments (Kotler, 1973). Retailers use lighting, color, music, and scents to stimulate customer perceptions and emotional responses and ultimately affect their buying behavior (Levy danWeitz, 2011). Cheng, Wu, and Yen (2009) researched about the store atmosphere devoted in music and color, the results of the research proves specifically that fast music is reported to be associated with a higher level of arousal and pleasure than slow music, while cool color is associated with a lower level of arousal and pleasure than warm color. Spies et. al (1997) argue the direct effect of store atmosphere as well as to an indirect effect mediated by customers' mood. Customers in the pleasant store spontaneously spent more money on articles they simply liked. Moreover, retail lighting also affects atmosphere with factors such as coziness, liveliness, tenseness and detachment and thereby shifts the emphasis of lighting to mean more than a factor of visibility (Schielke and Leudesdorff, 2015).

The development of retail business requires retailers provide more varied product to provide choices and fulfill consumer needs. This requires retailers to always provide adequate stock or supply merchandising. In addition to relying from suppliers, retailers can innovate businesses by providing or producing a product by labeling itself for sale at its store. Park, Park, and Dubinsky (2011), describes a private label brand is a product that is designed and sold by a retailer and is available for sale only from the retailer. Nowadays, retailers' brands are seen by consumers, at least in some markets and some product categories, as valuable substitutes to established manufacturers' or national brands (Martínherrán, 2008). Private label brand is used to increase shopping options for consumers. By using the retailers own brand, the product has a unique advantage, because it is definitely not going to be found in other retail (Sondakh, 2011). The existence of private label in Indonesia has been done by many retailers like Giant (Hero), Carefour, Hypermart, Alfamart, Indomaret. The growth of private label is one of the 
differentiation efforts undertaken by retailers and also efforts to build customers' loyalty. The existence of private label is expected to reinforce the impulse buyer's desire due to the limited availability of its products only in certain retail stores.

Impulse buying necessary to be maximized in order to increase retail sales, in this case the retailer must know the factors that can encourage it. Factors that are proven to have influence to managed and maximized as well as increasing sales can be achieved. This study aims to examine those factors through impulse buying; the researchers used the size of visual merchandising, store atmosphere and private label product. The result is expected to give contribution and recommendation for the retailer in maximizing the factors to improve impulse buying.

\section{Literature Review and Hypothesis}

\subsection{The relation of visual merchandising and impulse buying}

Retail business activity cannot be separated from the activities of arranging goods or merchandising. Visual merchandising is a substitute for sales person who aims to provide information and provide direction needed by customers indicated by signs, pictures or other media. It aims to introduce products in style and color, educating customers to get them to quick purchasing decisions. It is expected to increase interest in a brand or product on a display rack and influence consumers to buy more, so retailers get more sales and profits. Impulse buyer is a consumer behavior that buy spontaneously, suddenly and unplanned. The impulse buyer behavior is very easily influenced by what they see. Retailers can customize eye-catching displays, unique designs, or attractive packaging to increase purchases by impulse buyers. Four dimensions of visual merchandising such as window display, in-store form/mannequin display, floor merchandising and promotional signage are studied and its impact on impulse buying behavior is found that certain dimensions of visual merchandising do affect impulse purchase (Mehta and Chugan, 2013). Moayery, Zamani, and Vazifehdoost (2014) prove that there is a pivotal relation between young adult females' impulse buying behavior and three types of visual merchandising dimensions. (Sahni, Jain, and Jain, 2014) agreed that all four types of visual merchandising are significantly interrelated and that relationship generates the influences on young consumers' impulse buying behavior. Visual merchandising of window displays and in-store design make the highest impact on impulse buying (Gudonaviciene and Alijosiene, 2015). Otherwise, Bhatti (2014) found that forum display and windows display are negatively related to consumer impulse buying, but however, two dimension of visual merchandising are positively related to consumer impulse buying behavior such floor merchandising and shop brand name.

$\mathrm{H}_{1}$ : Visual merchandising has positive and significant effect on impulse buying

\subsection{The relation of store atmosphere and impulse buying}

Retailers need to create an atmosphere store that aims to stimulate consumers for going shopping. Setting store atmosphere provides consumers to take action of purchases. Store atmosphere by Levy and Weitz (2011) includes elements of store design, store layout, visual communication, lighting, music and scents. The elements are arranged in such a way as to create a store image in the minds of consumers. Impulse buyer is strongly influenced by stimulation, so the ease and convenience created through the store atmosphere can attract impulse buyer in the purchase action.

$\mathrm{H} 2$ : Store atmosphere has a positive and significant effect on impulse buying

\subsection{The relation of private label product and impulse buying}

The development of retail business today, requires retailers to be more innovative in attracting consumers. Strategies must be prepared as best as possible to reach the hearts of consumers over other competitors. For facing the competition, nowadays many retailers innovate by issuing products with their own brand. By using your own brand, the product has a unique advantage because it cannot be found anywhere else. According to Bhattacharya (2013), retailers should understand this phenomenon and take appropriate promotions to measure and expand their business, at least by differentiating through private label products. Private label product is a retailer differentiation business, in addition to providing product choices in shopping; private label aims to build consumer loyalty by offering exclusive products (Corstjens and Lal, 2000). Nevertheless, Ashokkumar and Gopal (2009) argue that private label products are known as cheap and low quality products. Ihalauw (2009), private label is divided into four types, 
including generic private label used for cheap products, low quality, copycat brands private label is a replica product or imitate the national famous brand and put as close to national brand, premium store brand Private labels used for premium quality products and become the most popular trends, value innovators is a retail business to add value by selling products with better quality but at a very good price. Due to the limited availability of private label products in certain retailers will attract impulse buyers to make purchasing actions. In addition, private label product is considered as an alternative product with relatively cheap price.

H3: Private label product has a positive and significant effect on impulse buying

\section{Methodology}

This research is conducted in hypermarket located in North Jakarta, Indonesia. The Hypermarket is selected because it is considered as a representative place and contains elements of indicators to be studied. Hypermarkets in North Jakarta include Carefour, Transmart, Hypermart and Lotte. The object of research is the hypermarket visitors; the study population is all visitors who made purchase transactions. The sampling technique used is non-probability sampling, because the number of population cannot be determined. The sampling method used is convenience sampling that is method based on the ease of the researcher in spreading the questionnaire directly with the object it encountered. The research data used is primary data sourced from the dissemination of questionnaires and interviews on the object of research. The minimum number of research objects is determined through multiple regressions, based on Hair et al (2006), the minimum number of samples is five multiple number of indicators in each research variable, so the minimum amount of data that must be met is 125 respondents data. The variables and indicators of the study are described in detail in table 1 of the following operational variables.

Table 1: Operationalization Variable

\begin{tabular}{|c|c|c|}
\hline Variable & Dimension & Indicators \\
\hline $\begin{array}{l}\text { Visual } \\
\text { merchandising }\left(X_{1}\right)\end{array}$ & $\begin{array}{ll}\text { 1. } & \text { Window } \\
\text { display } \\
\text { 2. } \\
\text { Mannequin } \\
\text { display } \\
\text { 3. Floor } \\
\text { merchandising } \\
\text { 4. Promotional } \\
\text { signage } \\
\text { 5. Assortment }\end{array}$ & $\begin{array}{l}\text { 1. The display window } \\
\text { present an interesting } \\
\text { product array } \\
\text { 2. good mannequin } \\
\text { display attracts visitors } \\
\text { 3. Floor merchandising is } \\
\text { arranged regularly, clean } \\
\text { and tidy for easy access } \\
\text { in search of products } \\
\text { 4. There are signs / } \\
\text { attributes for promotional } \\
\text { products that interest to } \\
\text { buy in the } \\
\text { 5. Goods arranged in } \\
\text { accordance with the } \\
\text { classification of types and } \\
\text { sizes make it easy to find } \\
\text { products }\end{array}$ \\
\hline $\begin{array}{l}\text { Store atmosphere } \\
\left(\mathrm{X}_{2}\right)\end{array}$ & $\begin{array}{ll}\text { 1. } & \text { Lighting } \\
\text { 2. } & \text { Layout } \\
\text { 3. } & \text { Visual } \\
& \text { communication } \\
& \text { (Color) } \\
\text { 4. } & \text { Music } \\
\text { 5. } & \text { Scent }\end{array}$ & 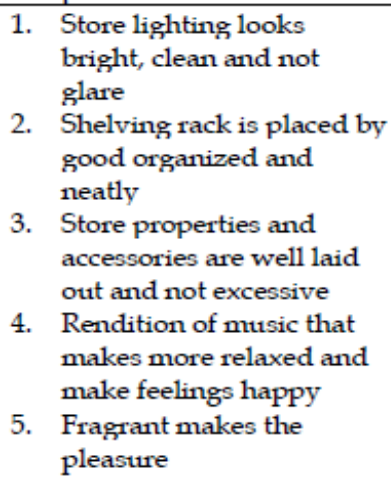 \\
\hline
\end{tabular}




\begin{tabular}{|c|c|c|}
\hline Variable & Dimension & Indicators \\
\hline $\begin{array}{l}\text { Private label } \\
\text { product (Z) }\end{array}$ & $\begin{array}{ll}\text { 1. } & \text { Packaging } \\
\text { 2. } & \text { Price } \\
\text { 3. } & \text { Quality } \\
\text { 4. } & \text { Value }\end{array}$ & $\begin{array}{l}\text { 1. Product's packaging } \\
\text { attract to buy } \\
\text { 2. Prices of affordable } \\
\text { products to buy } \\
\text { 3. Good product quality } \\
\text { 4. The benefits of the } \\
\text { product in accordance } \\
\text { with its usefulness }\end{array}$ \\
\hline Impulse buying(Y) & $\begin{array}{l}\text { 1. Unplanned } \\
\text { purchase } \\
\text { 2. Purchase } \\
\text { without } \\
\text { thinking the } \\
\text { consequences } \\
\text { 3. Emotion } \\
\text { 4. Promotion }\end{array}$ & $\begin{array}{l}\text { 1. Buy the product } \\
\text { unplanned } \\
\text { 2. Buy the product without } \\
\text { thinking due } \\
\text { 3. Buy the product because } \\
\text { it is in a happy feeling } \\
\text { 4. Buy a product because it } \\
\text { is proud to buy } \\
\text { 5. Buy the product to be } \\
\text { seen by others } \\
\text { 6. Buy a product because of } \\
\text { an attractive product } \\
\text { promotion }\end{array}$ \\
\hline
\end{tabular}

The research data used primary data sourced from the dissemination of questionnaires and interviews on the object of research. Questionnaires used questions that are measured by Likert's scale. The data is analyzed by Partial Least Square (PLS) which is a variant based Structural Equation Model (SEM) that can simultaneously perform model testing as well as structural model testing. PLS is a powerful tool used to test prediction models. Measurements using PLS will present the results of outer model evaluation and inner model. Outer model is a model of measurement to assess the validity and reliability of the model, whereas the inner model is a structural model to predict the causality relationship between latent variables.

\section{Result and Discussion}

Statistical test results are divided into two parts, the first is predicting causality among indicators in the structural model (outer model), the second is hypothesis testing (inner model). Causality relationship can be done with construct validity test and reliability test, while hypothesis test is presented by the value of path coefficient.

\subsection{Construct Validity}

To predict relational in structural models, the first measurement models should be performed for validation of indicators and latent variables. Validity test can be seen from cross loading value, rule of thumbs for cross loading is more than 0.5. It presents the value of outer loading for each indicator in table 2. It presents some indicators are invalid in forming variables. Invalid indicators should be removed (dropped) from the model. The validity testing constructs can also be seen from the Average Variance Extracted (AVE). The AVE score is the average percentage of the variance score extracted from a set of latent variables estimated through standardize loading in the algorithm iteration process (Hair et al., 2006).

$$
A V E=\frac{\sum_{i} \lambda_{i j}{ }^{2}}{\sum_{i} \lambda_{i j}{ }^{2}+\sum_{i} \operatorname{Var}\left(\varepsilon_{i}\right)}
$$


Table 2. Cross Loading

\begin{tabular}{|c|c|c|c|c|}
\hline & $\begin{array}{c}\text { Impulse } \\
\text { Buying }\end{array}$ & $\begin{array}{c}\text { Private Label } \\
\text { Product }\end{array}$ & $\begin{array}{c}\text { Store } \\
\text { Atmosphere }\end{array}$ & $\begin{array}{c}\text { Visual } \\
\text { Merchandising }\end{array}$ \\
\hline X1P1 & & & & 0.65 \\
\hline X1P2 & & & & 0.88 \\
\hline X1P3 & & & & 0.77 \\
\hline X1P4 & & & & -0.02 \\
\hline X1P5 & & & & 0.65 \\
\hline $\mathrm{X} 2 \mathrm{P} 1$ & & & 0.78 & \\
\hline $\mathrm{X} 2 \mathrm{P} 2$ & & & 0.92 & \\
\hline $\mathrm{X} 2 \mathrm{P} 3$ & & & 0.82 & \\
\hline $\mathrm{X} 2 \mathrm{P} 4$ & & & 0.49 & \\
\hline X2P5 & & & 0.91 & \\
\hline X3P1 & & 0.83 & & \\
\hline X3P2 & & 0.83 & & \\
\hline X3P3 & & 0.36 & & \\
\hline X3P4 & & -0.79 & & \\
\hline YP1 & 0.87 & & & \\
\hline YP2 & 0.80 & & & \\
\hline YP3 & -0.24 & & & \\
\hline YP4 & 0.22 & & & \\
\hline YP5 & 0.82 & & & \\
\hline YP6 & 0.59 & & & \\
\hline
\end{tabular}

The rule of validity AVE value is more than 0.5 . This means that the probability of an indicator in a construct going into another variable is lower, so that the probability of the indicator converges and enters the construct above 50 percent. Test results shown in table 3, the impulse buying and visual merchandising variables are not valid with successive values of 0.42 and 0.44 . So it needs to be re-test the valid indicators.

\subsection{Reliability Testing}

Reliability testing can be seen from the value of Conbrach's alpha and Composite Reliability. Conbrach's alpha is a statistical technique is used to measure internal consistency in instrument reliability tests or psychometric data. The value of Conbrach's alpha is said to be reliable if the value more than 0.6. While composite reliability is a statistical technique to measure the value of real reliability. The value of composite reliability is said to be reliable if the value more than 0.7 . The reliability test results are shown in Table 4.

Tabel 4.Conbrach's Alpha, Composite Reliability and AVE

\begin{tabular}{lccc}
\hline & $\begin{array}{c}\text { Conbrach's } \\
\text { Alpha }\end{array}$ & $\begin{array}{c}\text { Composite } \\
\text { Reliability }\end{array}$ & AVE \\
\hline $\begin{array}{l}\text { Impulse } \\
\text { Buying }\end{array}$ & 0.57 & 0.73 & 0.42 \\
$\begin{array}{l}\text { Private Label } \\
\text { Product }\end{array}$ & 0.12 & 0.45 & 0.53 \\
$\begin{array}{l}\text { Store } \\
\text { Atmosphere }\end{array}$ & 0.84 & 0.89 & 0.64 \\
$\begin{array}{l}\text { Visual } \\
\text { Merchandising }\end{array}$ & 0.66 & 0.75 & 0.44 \\
\hline
\end{tabular}

The result of reliability test obtained if impulse buying and private label product does not suffice the minimum value of Conbrach's Alpha, while the value of Composite Reliability show that impulse buying value is not reliable. 


\subsection{Fit Model}

Based on the previous test found some indicators that aren't valid or reliable must be removed from the model, then re-testing required. The results of the fit model after re-testing stated in the test construct validity and reliability shows in table 5 and table 6.

Tabel 5.Cross Loading after Fit Model

\begin{tabular}{lcccc}
\hline & $\begin{array}{c}\text { Impulse } \\
\text { Buying }\end{array}$ & $\begin{array}{c}\text { Private Label } \\
\text { Product }\end{array}$ & $\begin{array}{c}\text { Store } \\
\text { Atmosphere }\end{array}$ & $\begin{array}{c}\text { Visual } \\
\text { Merchandising }\end{array}$ \\
\hline X1P1 & & & & 0.60 \\
X1P2 & & & & 0.91 \\
X1P3 & & & 0.75 & 0.74 \\
X1P5 & & & 0.94 & \\
X2P1 & & & 0.85 & \\
X2P2 & & & 0.93 & \\
X2P3 & & & & \\
X2P5 & & 0.87 & & \\
X3P1 & & 0.83 & & \\
X3P2 & & & & \\
YP1 & 0.91 & & & \\
YP2 & 0.80 & & & \\
YP5 & 0.81 & & & \\
YP6 & 0.57 & & & \\
\hline
\end{tabular}

The results of the test back then obtained the result that all indicators have valid to build latent variables. The value of outer loading is $>0.5$ and AVE $>0.5$. Then the hypothesis model testing can be done.

Tabel 6.Conbrach's Alpha, Composite Reliability and AVE after Fit Model

\begin{tabular}{lccc}
\hline & $\begin{array}{c}\text { Conbrach's } \\
\text { Alpha }\end{array}$ & $\begin{array}{c}\text { Composite } \\
\text { Reliability }\end{array}$ & AVE \\
\hline $\begin{array}{l}\text { Impulse } \\
\text { Buying } \\
\text { Private Label }\end{array}$ & 0.79 & 0.86 & 0.61 \\
$\begin{array}{l}\text { Product } \\
\text { Store } \\
\text { Atmosphere }\end{array}$ & 0.61 & 0.84 & 0.72 \\
$\begin{array}{l}\text { Visual } \\
\text { Merchandising }\end{array}$ & 0.89 & 0.93 & 0.76 \\
\hline
\end{tabular}

The result of the fit model indicates that the indicator in each variable has been reliable. The value of Conbrach's Alpha > 0.6 and Composite Reliability> 0.7 .

\subsection{Hypothesis testing}

The result of hypothesis testing is significant if the value of T-statistic is more than 1.96 (P-Value < 0.05). Based on table 7, it obtained visual merchandising, store atmosphere and private label product has positive and significant effect on impulse buying with T-statistic value $2.25 ; 14.02 ; 5.51$. It means that the entire hypothesis is proved.

Tabel 7. Path Coefficient

\begin{tabular}{lccccc}
\hline & $\begin{array}{c}\text { Original } \\
\text { Sample }\end{array}$ & $\begin{array}{c}\text { Sample } \\
\text { Mean }\end{array}$ & $\begin{array}{c}\text { Standard } \\
\text { Deviation }\end{array}$ & $\begin{array}{c}\text { T- } \\
\text { Statistic }\end{array}$ & $\begin{array}{c}\text { P- } \\
\text { Values }\end{array}$ \\
\hline $\begin{array}{l}\text { Visual } \\
\text { Merchandising } \rightarrow\end{array}$ & 0.279 & 0.15 & 0.06 & 2.25 & 0.02 \\
$\begin{array}{l}\text { Impulse Buying } \\
\text { Store Atmosphere } \rightarrow\end{array}$ & 0.711 & 0.70 & 0.05 & 14.02 & 0.00 \\
$\begin{array}{l}\text { Impulse Buying } \\
\text { Private Label } \\
\text { product } \rightarrow \text { Impulse } \\
\text { Buying }\end{array}$ & 0.133 & 0.29 & 0.05 & 5.51 & 0.00 \\
\hline
\end{tabular}

www.jbrmr.com A Journal of the Academy of Business and Retail Management (ABRM) 
The research revealed respondent is attracted by mannequin display which increase perceived values of the consumers till determine to purchase the product. It mostly done by fashion product such clothes and shoes. The second result revealed store atmosphere which is represented by shelving rack which is placed neatly organizes really helps consumers to find the product and increase the passionate to buy. The third result is that private label product with low price lead the consumers for doing unplanned purchasing. The respondents state that the average of them is coming to the hypermarket with shopping list but it can be easily influenced by the interesting store displays.

\section{Conclusion}

The retail business must determine the strength of impulse buyer which is able to increase purchasing number. Visual merchandising which is measured by windows display, mannequin, floor merchandising and assortment has positive and significant effect on impulse buying. Store atmosphere attractively has positive and significant on impulse buying which is measured by lighting, layout, visual communication (color) and scent on the store. In order to, the mount of impulse buying can be affected by create private label product. The unique packaging and low price really diluted by consumers. These three aspects proved become determinant factors affecting impulse buying.

\section{Limitation}

During the observation to the respondent, researcher found that there is another variable that's not measured in this research such as product promotion. An interesting promotional is the other indicator which is not further investigated. For future research can improve the limitation of this research for measure the other variables affecting impulse buying such as sales promotion.

\section{References}

Ashokkumar, S., and Gopal.2009. Diffusion of Innovation in Private Labels in Food Products. The ICFAI University Journal of Brand Management, Vol. 6, No.1

Bhalla, S. \& Anuraag, S. 2010. Visual Merchandising. New Delhi: McGraw Hill

Bhattacharya, Debasis, Shuvendu Dey. 2013. A Study of Impulsive Buying Behavior towards Private Label Brands at Organized Retail Stores: A Multivariate Analysis. Indian Journal of Research. Vol. 2, Issue: 7

Bhatti, Khurram L. 2014. The Impact of Visual Merchandising on Consumer Impulse Buying. Eurasian Journal of Business Vol. 2, No. 1

Cant, Michael C. 2013a. Visual Merchandising Displays: Positive or Negative Effect on Consumer Behaviour?. Gender \& Behaviour Vol. 11, No. 2

- - - 2013b. Visual Merchandising Displays - Functional or A Waste of Space in Apparel Retail Stores?. Gender \& Behaviour Vol. 11(June)

Cheng, Fei-Fei, Chin-Shan Wu, and David C Yen. 2009. The Effect of Online Store Atmosphere on Consumer's Emotional Responses - An Experimental Study of Music And Colour. Behaviour $\mathcal{E}$ Information Technology, Vol. 28, No. 4,

Corstjens M., and Lal R. 2000.Building Store Loyalty through Store Brands. Journal of Marketing Research, Vol. 37, No. 3, Pp. 281-291.

Hair, Joseph F., William C. Black, Barry J. Babin, Rolph E. Anderson, \&Roland L. Tatham. 2006. Multivariate Data Analysis, 6th Edition. Prentice Hall.

Ihalauw, John. 2009. Retail Private Label. Graduate Certificate Program Level 2.

Jung, Joowon. 2017. Impact of Motives on Impulsivity and Compulsivity in Compulsive Buying Behavior. Social V=Behavior and Personality. Vol. 45, No. 5

Khandai, Sujata. 2012. Visual Merchandising as An Antecedent to Impulse Buying: An Indian Perspective. International Journal Of Business And Management StudieVol. 1, No. 1

Levy, M., \&Weitz, B. 2011. Retailing Management (8th Ed.). Mcgraw-Hill Education

Li, Yalin. 2015. Impact of Impulsive Buying Behavior on Postimpulsive Buying Satisfaction. Social Behaviour and Personality, Vol. 43, No. 2

Martín-Herrán, Nawel Amrouche Guiomar. 2008. Feedback Stackelberg Equilibrium Strategies When The Private Label Competes With The National Brand. Ann Oper Res Vol. 164

Mehta, Neha P, And Pawan K Chugan. 2013. The Impact of Visual Merchandising on Impulse Buying 
Behavior of Consumer: A Case from Central Mall of Ahmedabad India. Universal Journal of Management, Vol.1, No. 2

Moayery, Meysam, Samar Zamani, and Hosein Vazifehdoost. 2014. Effect of Visual Merchandising on Apparel Impulse Buying Behaviors Among Iranian Young Adult Females. Indian Journal of Science and Technology. Vol. 7, No. 3

Park, Jin Yong, Kyungdo Park, And Alan J Dubinsky. 2011. Impact Of Retailer Image On Private Brand Attitude: Halo Effect and Summary Contstruct. Australian Journal and Psychology, Vol. 63

Kotler, Philip. 1973. Atmospherics As A Marketing Tool. Journal of Retailing, Vol. 49. No 4

Gudonaviciene, Rasa and Sonata Alijosiene. 2015. Visual Merchandising Impact on Impulse Buying Behaviour.20th International Scientific Conference Economics and Management

Rook, D.W. \&Fisher, R.J. 1995.Normative Influences on Impulsive Buying. Journal of Consumer Research.Vol.22

Sahni, Deepak, Vipul Jain, and Arvind Jain. 2014. The Impact of Visual Merchandising on Impulsive Buying Behavior of Young Consumers. Asian Journal of Business and Economics. Vol. 4, No. 4

Schiffman, L. G. \&Kanuk, L. 2007. Consumer Behavior. Ninth Edition. Pearson Prentice Hall

Singh, Atul Sen and Satish Kumar. 2015. Impact of Visual Merchandising on Brand Equity: An Empirical Study on Premium Apparel Retailers. International Journal of Multidisciplinary Approach and Studies. Vol. 2, No. 6

Sondakh, Oliandes. 2011. Materialism Behavior On Private Label Buying Decision Among Indonesian Teenagers. The 1st International Conference on Information Systems For Business Competitiveness (ICISBC)

Schielke, T., and M Leudesdorff. 2015. Impact of Lighting Design on Brand Image For Fashion Retail Stores. Lighting Res. Technol. Vol. 47

Spies, K., Hesse, F., And Loesch, K., 1997. Store Atmosphere, Mood, and Purchasing Behavior. International Journal of Research in Marketing, Vol. 14 (February)

Verplanken, BAS., and Astrid Herabadi. 2001. Individual Differences in Impulse Buying Tendency: Feeling and No Thinking.European Journal of Personality Vol. 15 